\title{
EPS Producing Microorganisms from Municipal Wastewater Activated Sludge
}

\section{Klai Nouha ${ }^{1}$, Yan S ${ }^{1}$, Tyagi RD ${ }^{1 *}$ and Surampalli RY ${ }^{2}$}

${ }^{1}$ Université du Québec, Institut national de la recherche scientifique, Centre Eau, Terre and Environnement, 490 de la Couronne, Québec, G1K 9A9, Canada ${ }^{2}$ Department of Civil Engineering, University of Nebraska-Lincoln, Lincoln, NE 68588-6105, USA

\begin{abstract}
Bacterial exopolysacchrides (EPSs) are produced by many bacteria. Nowadays there is an increasing interest in the isolation and exploitation of these polymers for industrial purposes. In general, biosynthesis of EPS varies from one strain to other strain and it depends on genes and enzymes involved in EPS production and secretion. In this study, EPS producing strains were isolated from municipal wastewater treatment plant and their potential of EPS production was evaluated. The role of EPS in sludge flocculation was also studied. Three types of EPS (LB-EPS (Loosely bound EPS), TB-EPS (Tightly bound EPS) and B-EPS (broth EPS)) were harvested and their characteristics were studied. The bioflocculation capacity of the obtained EPS was evaluated by measuring the kaolin clay flocculation activity. The LB-EPS was better than TB-EPS and B-EPS for bioflocculation.
\end{abstract}

Keywords: Strain producing EPS isolation; EPS production; Bioflocculation

\begin{abstract}
Abbreviations: APHA: American Public Health Association; AS: Activated Sludge; Asn: Asparagine; Asp: Aspartic Acid; B-EPS: Broth EPS; Bc: Organic Load Rate; BOD: Biochemical Oxygen Demand; BSA: Bovine Serum Albumin; TB-EPS: tightly bound EPS; CA: Colanic Acid; CFU: Colony Forming Units; CG: Cytosine/Guanine; C/N: Carbon To Nitrogen; COD: Chemical Oxygen Demand; Cps: Capsular Polysaccharide Synthesis; CST: Capillary Suction Time; CUQ: Communauté Urbaine Du Québec; DLVO: Derjaguin And Landau: Verwey And Overbeek; DNA: Deoxyribonucleic Acid; Dtdp: Désoxythymidine Diphosphate; EPS: Extracellular Polymeric Substances; E. Coli: Escherichia. Coli; FA: Flocculation Activity; F/M: Food/Microorganisms; Glu: Glutamic Acid; Gly: Glycine; IF: Inoculation Fluid; LAB: Lactic Acid Bacteria; Lb: Lactobacillus; LBEPS: Loosely Bound EPS; MWWP: Municipal wastewater treatment plant; Mg EPS/G Of Kaolin: Mg Of EPS Added Per Gram Of Kaolin Suspension In Water; Orfs: Open Reading Frame; PCA: Plate Count Agar; PCR: Real-Time PCR; Rrna: Ribosomal Ribonucleic Acid; LBEPS: Loosely bound EPS; SRT: Solid Retention Time; SS: Suspended Solids; TB-EPS: Tightly Bound EPS; TSB: Typtic Soy Broth; TSS: Total Suspended Solid; WWS: Wastewater Sludge; WWTP: Wastewater Treatment Plant; Z: Zeta Potential
\end{abstract}

\section{Introduction}

Activated sludge is the most commonly used biological process for wastewater treatment. Normal practice in wastewater treatment plants is to employ the use of synthetic polymers for enhancement of sludge settling. These synthetic polymers have many disadvantages; they are expensive, toxic and can pollute the environment [1]. Thus, high flocculation potential, low cost, environment friendly and sustainable biopolymers (e.g., chitosan, sodium alginate and microbial flocculants) are being searched by many researchers $[2,3]$. Extracellular polymeric substances (EPSs) are of considerable importance in the removal of pollutants from wastewater, in bioflocculation and settling and in the dewatering of activated sludge [2]. EPSs are located outside the cell surface and can be subdivided into bound and soluble EPSs. The bound EPS are closely bound with cells, due to many functional groups (carboxyl, phosphoric, sulfhydryl, phenolic and hydroxyl group) and apolar groups (e.g., aromatics, aliphatics in proteins, and hydrophobic regions in carbohydrates and proteins). The soluble EPSs are weakly attached to cells or dissolved into the solution that can be explained by the hydrophilic fraction mainly consisted of carbohydrates.

Activated sludge is comprised of a wide variety of microbial community, containing many types of viruses, bacteria, protozoa, fungi, metazoa and algae. In this complex environment, bacteria, which usually make about $95 \%$ of the total microbial population, play a key role in efficiently eliminating the organic material and other pollutants from wastewater under highly oxygenated conditions. Majority of these microbial species were immobilized in EPS or matrices made of polymers of necessary protein, polysaccharides, humic substances, and lipids [4].

EPS producing bacterial species are very efficient in converting nutrients into EPS. Considering the tendency in nature to conserve rather than to waste, this expenditure of energy is likely to hold benefits to the producers of EPS, as well as those organisms associated with them. Therefore, the EPS synthesis by microbial cells depends upon availability of the carbon and nitrogen in the culture medium and environmental conditions. The organisms differ in their carbon and nitrogen source utilization, mineral requirements, temperature and $\mathrm{pH}$, which are the critical factors for maximum EPS production [5]. To understand the EPS production abilities of bacterial species growing in wastewater treatment plant and accumulated in wastewater sludge, it is necessary to have information or knowledge of their metabolic pathway, their genes, biochemical properties, and vulnerability to certain chemical substances and anti-microbial agents. Various research on EPS biosynthesis have been conducted [6], however, only few were directed towards the production of EPS using low-cost medium. Moreover, few studies investigated the variation of microbial community in WWTP with respect to seasonal changes due to the variation of environmental factors particularly the temperature and the

*Corresponding author: Tyagi RD, Institut national de la recherche scientifique Centre Eau, Terre and Environnement, Canada, Tel: +1 418654 2617; E-mail: rd.tyagi@ete.inrs.ca

Receive October 06, 2015; Accepted December 02, 2015; Published December 12, 2015

Citation: Nouha K, Yan S, Tyagi RD, Surampalli RY (2015) EPS Producing Microorganisms from Municipal Wastewater Activated Sludge. J Pet Environ Biotechnol 7: 255. doi:10.4172/2157-7463.1000255

Copyright: $\odot 2015$ Nouha K, et al. This is an open-access article distributed under the terms of the Creative Commons Attribution License, which permits unrestricted use, distribution, and reproduction in any medium, provided the original author and source are credited. 
composition of wastewater. There were few researches [7] comparing the EPS production among the strains based on their genetics. This study presented three parts. Isolation and identification of new strains, which could produce high EPS concentration. Secondly, the effect of environmental factors, specifically, the temperature on EPS production and on the total variation of EPS producing microbial community. Finally, the EPS production variation among the strains, the difference in their physicochemical characteristics (polysaccharides and proteins content) and the improvement of their activities as bio-flocculants in comparison to previous studies.

\section{Materials and Methods}

\section{Isolation of EPS producing strains from wastewater sludge}

EPS producing bacteria were isolated from wastewater sludge (WWS) collected from Communauté Urbaine du Québec (CUQ, Québec, Canada). Microbial isolation was carried out by incubating appropriate serial dilutions of WWS on plate count agar (PCA) at $30^{\circ} \mathrm{C}$ for $48-72 \mathrm{~h}$. Among the Colony forming unit (CFU) formed on PCA, EPS producing microorganisms were selected based on their ability to form string (indicating EPS production) while touching with inoculating loop. Congo red was employed to identify the capsular EPS (TB-EPS) [8].

\section{Molecular identification and sequences analysis}

Potential EPS producing bacterial isolates were identified genetically by adopting $16 \mathrm{~S}$ rRNA Sangers sequencing technology. Total genomic DNA of all the bacterial strains was extracted by using Qiagen DNA extraction kit according to manufactures instructions. Polymerase chain reaction of these genomic DNA was carried out to amplify the 16S rRNA region using a primer set of 9F:5'-gagtttgatcctggtcag- 3 ' and 1512R:5'-acggtaccttgttacgac-3' [9]. Primers were synthesized from Integrated DNA technologies USA. PCR reaction mix of $50 \mu \mathrm{L}$ reaction volume contains 1X PCR master mix from promega, USA and 100 pmol of each oligonucleotide primers and template DNA $(0.25 \mathrm{mg}$ of purified DNA from $1 \mathrm{mg} / \mathrm{mL}$ of stock solution) of 8 different bacterial isolates (NK2-NK9). PCR reaction cycle includes; denaturation at $95^{\circ} \mathrm{C}$ for $5 \mathrm{~min}, 30 \mathrm{~s}$, annealing at $51^{\circ} \mathrm{C}$ for $30 \mathrm{~s}$ and polymerization at $72^{\circ} \mathrm{C}$ for $1 \mathrm{~min}, 30 \mathrm{~s}$ for $35 \mathrm{cycles}$ followed by final extension at $72^{\circ} \mathrm{C}$ for 10 min. PCR amplica of $1503 \mathrm{bp}$ were eluted, purified and suspended in Milli Q water for sequencing.

PCR amplica were subjected to Sanger's sequencing using ABI 3730xl DNA Analyzer, Applied biosystems, USA. Thus obtained sequencing data were aligned using DNASIS bioinformatics software (Hitachi Software Japan, Tokyo) and were blasted against 16S rRNA sequences (BLSTn) for sequence homology followed by submission in NCBI (National Center for Biotechnology Information) gene bank via with accession numbers from KF675198 to KF675205.

Using the gene sequence information, the multiple alignment of gene sequences, phylogenetic tree (neighbourhood joining method) were predicted using DNASIS software, version4.

\section{Biochemical identification}

EPS producers were subjected to biochemical identification via Biolog substrate utilization profile. For Biolog identification of bacterial strains, according to manufactures protocols Biolog Gen III plates were incubated with $100 \mu \mathrm{L}$ of the bacterial suspensions in inoculation fluid (IF) provided at $30^{\circ} \mathrm{C}$ for $24-48 \mathrm{~h}$. Substrates utilization is indicated when a purple colour appears in micro titre wells and no reactions was recorded if remains colour less. Growth of the bacterial strains at different $\mathrm{pH}$, carbon sources, amino acids/proteins, carboxylic acids, and esters, fatty acids and presence of antibiotic or reducing power was determined by the change in colour towards purple.

\section{Sludge as bacterial source and as growth medium}

The sludge was concentrated on spot by removing the supernatant after gravity settling for $1 \mathrm{~h}$. Concentrated sludge was stored at $4^{\circ} \mathrm{C}$ for less than $24 \mathrm{~h}$ before use to ensure that there was no sludge degradation during storage. Characteristics of the sludge, such as $\mathrm{pH}$, total suspended solids (TSS), and volatile suspended solids (VSS), total carbon and total nitrogen were determined using Standard Methods [10]. Viscosity was measured by viscometer (DV-II + PRO, Brookfield Engineering Laboratories, Inc., Stoughton, MA, USA), at constant higher shear rate of $20 \mathrm{~s}^{-1}$ and at room temperature. Zeta potential $(\zeta)$ was measured using Zetaphoremeter (Zetaphoremeter IV, Zetacompact Z8000, CAD Instrumentation, France).

\section{EPS production and harvesting}

Inoculum of all the bacterial strains was prepared in sterilized sludge $\left(121^{\circ} \mathrm{C}\right.$ for $\left.30 \mathrm{~min}\right)$ at $\mathrm{pH} 7$ by incubating at $30^{\circ} \mathrm{C}$ and at $180 \mathrm{rpm}$ for $24 \mathrm{~h}$. Fermentation for EPS production was performed by incubating $150 \mathrm{~mL}$ of sterilized sludge in $500 \mathrm{~mL}$ Erlenmeyer flasks at $180 \mathrm{rpm}$, $30^{\circ} \mathrm{C}$ for $72 \mathrm{hr}$ which was inoculated with $3 \%$ inoculum. Standard plate count method was adopted to determine the bacterial strain growth and was reported as CFU/mL. EPS produced were estimated after $48 \mathrm{~h}$ and at the end of the cultivation $(72 \mathrm{~h})$. After fermentation, broth samples were centrifuged at $6000 \mathrm{~g}$ for $20 \mathrm{~min}$ at $4^{\circ} \mathrm{C}$ to obtain supernatant (containing loosely bound EPS; termed as LB-EPS) and pellets (containing tightly bound EPS or TB-EPS) with bacterial cells along with residual sludge material and termed as TB-EPS) [2]. LB-EPS in the supernatant was precipitated by incubating with 2 times volume of absolute ethanol at $-20^{\circ} \mathrm{C}$ for $24 \mathrm{~h}$. The precipitates (containing pure LB-EPS) were collected by centrifugation at $6000 \mathrm{~g}$ for $20 \mathrm{~min}$ at $4^{\circ} \mathrm{C}$. Precipitates of LB-EPS were dried at $60^{\circ} \mathrm{C}$ for $24 \mathrm{~h}$ and dry weight of the precipitates was measured and denoted as LB-EPS [10]. To determine TB-EPS, the pellet (crude TB-EPS) was re-suspended in deionized water, first heated in water bath at $60^{\circ} \mathrm{C}$ for $30 \mathrm{~min}$ to release TB-EPS followed by centrifugation at $6000 \mathrm{~g}$ for $20 \mathrm{~min}$ at $4^{\circ} \mathrm{C}$ [3]. The supernatant (containing TB-EPS) was used to precipitate TB-EPS using same procedure as for LB-EPS. Dry weight of precipitates was measured and denoted as the concentration of TB-EPS produced. Sum of dry weights of LB-EPS and TB-EPS (measured above) was denoted as total broth EPS (B-EPS). The protein content in LB-EPS and TB-EPS was determined by Bradford [11] method using bovine serum albumin (BSA) as a standard. The carbohydrate content of the total EPS was determined by the phenol-sulphuric acid method using glucose as the standard [12].

\section{Characterization of EPS}

EPS extracted from different isolates was characterized by analysing its viscosity, Zeta potential and flocculation activity.

Viscosity: Viscosity was measured for all different types of EPS (broth, slime and capsular) produced by bacteria after 3 days of fermentation. $20 \mathrm{~mL}$ of the culture (bacterial) broth was used to measure the viscosity using ULA S 34 spindle (Digital Viscometer, DVII+ Pro, Brookfield), at $60 \mathrm{rpm}$ and room temperature.

Zeta potential: The charge of each type of EPS was determined by adding $50-1000 \mu \mathrm{L}$ of individual EPS sample to $100 \mathrm{~mL}$ of deoinzed 
water. The zeta potential of different EPS (Broth, slime and capsular EPS) was determined from individual bacterial grown media (noncentrifuged media) after 3 days of fermentation. The surface charge or zeta potential $(\zeta)$ measurements were carried out using three types of EPS obtained from all bacterial strains isolated. Characterization of charge (zeta potential) was implemented using Zetaphoremeter (Zetaphoremeter IV, Zetacompact Z8000, CAD Instrumentation, France) with the application of the Smoluckowski equation. Surface charge of the wastewater sludge was also measured. The zeta potential values were obtained from an average of around 10 measurements, the average values are presented with its half-width confidence interval at $95 \%$ confidence level.

Kaolin flocculation activity of different EPS: Flocculation activities of the EPS were based on a decrease in turbidity of the standard kaolin suspension after jar tests. The jar tests were performed using kaolin suspension $(5 \mathrm{~g} / \mathrm{L})$ prepared in deionized water. Divalent cation $\left(\mathrm{Ca}^{2+}\right)(150 \mathrm{mg} / \mathrm{L}$ dissolved in deionized water $)$ was added to the kaolin suspension of $500 \mathrm{~mL}$ by rapid mixing ( $180 \mathrm{rpm}$ for $3 \mathrm{~min}$ ) and then $\mathrm{pH}$ was adjusted to 7 by adding $\mathrm{NaOH}(1 \mathrm{M})$ [13]. The samples collected from bacterial isolates at $48 \mathrm{~h}$ and $72 \mathrm{~h}$ were added in different volumes (corresponding to desired concentrations of EPS, which was calculated through dry weight and the volume of EPS solution was added accordingly) to kaolin suspension and rapidly mixed at 100 $\mathrm{rpm}$ for an initial $5 \mathrm{~min}$ then slowly mixed for an additional $30 \mathrm{~min}$ at $70 \mathrm{rpm}$. After $35 \mathrm{~min}$ of mixing, samples were transferred to a 500 $\mathrm{mL}$ cylinder where they settled for $30 \mathrm{~min}$ and supernatants were then collected to measure the turbidity using turbidimeter (Micro 100 turbidimeter, Scientific Inc.). Flocculation activity was calculated according to the equation: Flocculation activity $=\left[100^{\star}(\mathrm{C}-\mathrm{S}) / \mathrm{C}\right](\%)$, where $\mathrm{C}$ is control turbidity and $\mathrm{S}$ is sample turbidity.

\section{Results and Discussion}

\section{Isolation and characterization of EPS producing bacterial strains}

Eight (named NK2 to NK9) bacterial strains were isolated from the municipal wastewater sludge. These microorganisms were selected based on their mucoidal colony formation on the PCA agar plates and string forming ability by touching with inoculating loop (Figure 1a). All these bacterial strains were screened to study their potential for EPS production. All of the bacterial strains were identified as gram negative except Brevibacillus parabrevis and Acinetobacter parvus (Table 1, Figures $1 \mathrm{a}$ and $1 \mathrm{~b}$ ). Whereas all the isolated strains were capable of producing LB-EPS. The strain NK6 was the best which could form an EPS string longer than $3 \mathrm{~cm}$ among all strains (Figure 1).

The $16 \mathrm{~S}$ rDNA sequence data were subjected to a BLASTn search tool of NCBI and the homology search results of NK2-NK9 bacterial strains resembling (96-99\%) with existing DNA sequence database were identified. The accession numbers of isolated strains submitted to genbank are provided in Table 1.

\section{DNA characteristics and sequences analysis of isolated strains}

EPS production by different strains varied greatly. The EPS concentration $(11.8 \pm 1.2 \mathrm{~g} / \mathrm{L})$ produced by Cloacibacterium normannese is the highest among all EPS producing strains isolated from wastewater sludge in this study and the previous studies $[2,3,14]$. The difference in EPS concentration could be explained by the genetics organisation of the EPS biosynthesis gene cluster among strains. The difference in gene structure, sugar precursor biosynthesis and regulatory elements among the strains could be the reason for the diversity in EPS production levels, their composition, their charge, which displayed different patterns in kaolin flocculation.

The gene sequences analysis and its relation to the EPS production has attracted the attention of many researchers $[7,13,15]$. In general, genetic elements required for EPS production include genes encoding regulation, chain length determination, repeat -unit assembly, polymerisation and export.

The similarity analysis among all eight EPS producing bacterial strains was carried out by drawing a dendrogram using the neighbourhood joining method. Multiple alignments of gene sequences was done followed by aligned sequences which was treated
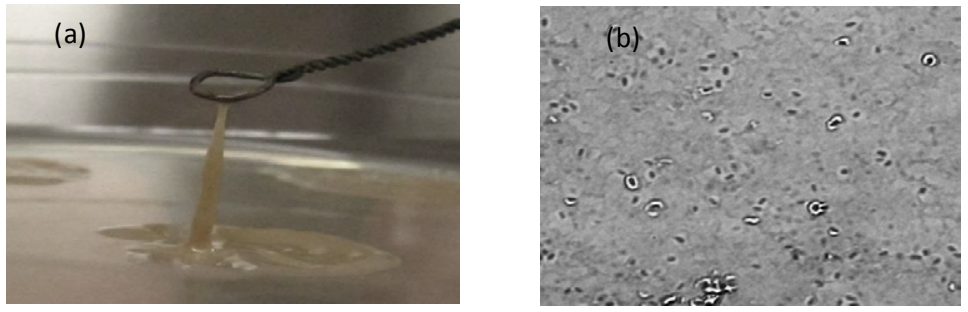

Figure 1: (a) Slime EPS producing bacterial strain (NK6) showing string of secreted biopolymer on PCA agar plate, (b) Capsular staining results revealed the presence of capsular Extracellular polymer substances in isolated strains (NK5).

\begin{tabular}{|c|c|c|c|c|c|c|}
\hline \multirow{2}{*}{$\begin{array}{l}\text { Bacterial strains } \\
\text { code }\end{array}$} & \multicolumn{3}{|c|}{ Staining } & \multirow[t]{2}{*}{ Bacterial Identifiacation } & \multirow{2}{*}{$\begin{array}{l}\text { Viscosity of fermented } \\
\text { Broth }(\mathrm{mPa})\end{array}$} & \multirow[t]{2}{*}{ Accession number } \\
\hline & Slime EPS & Capsular EPS & Gram staining & & & \\
\hline NK2 & + & + & Negative & Chryseobacterium gregarium & $10.0 \pm 0.9$ & KF675198 \\
\hline NK3 & + & + & Negative & Staphylococcus epidermidis & $8.6 \pm 0.5$ & KF675199 \\
\hline NK4 & + & + & Negative & Stenotrophomonas acidaminiphila & $10.8 \pm 1.1$ & KF675200 \\
\hline NK5 & + & + & positive & Brevibacillus parabrevis & $15.8 \pm 0.8$ & KF675201 \\
\hline NK6 & + & + & Negative & Cloacibactéruim normanense & $85.7 \pm 1.9$ & KF675202 \\
\hline NK7 & + & + & Negative & Pseudomonas veronii & $7.8 \pm 1.4$ & KF675203 \\
\hline NK8 & + & + & Negative & Acinetobacter soli & $10.0 \pm 0.9$ & KF675204 \\
\hline NK9 & + & + & Positive & Acinetobacter parvus & $8.7 \pm 0.5$ & KF675205 \\
\hline
\end{tabular}

Table 1: Molecular identification and microbiological characterization of EPS producing bacterial strains isolated from municipal wastewater sludge. 
Citation: Nouha K, Yan S, Tyagi RD, Surampalli RY (2015) EPS Producing Microorganisms from Municipal Wastewater Activated Sludge. J Pet Environ Biotechnol 7: 255. doi:10.4172/2157-7463.1000255

Page 4 of 13

for phylogenetic tree construction (Figures $2 \mathrm{a}$ and $2 \mathrm{~b}$ ), which revealed the relatedness among the microbial strains. The multiple alignments of gene sequences were conducted for all bacterial strains (NK2-NK9) isolated from wastewater sludge (Figure 2a). Each strain is apparent in specific genes clusters. The conservation of gene sequences varied which confirmed that each strain was significantly different from each other.

There was little variation between the strains having same genus and species such as Acinetobacter parvus and Acinetobacter soli which is apparent in one cluster (Figure 2b). It was observed that Cloacibacterium normanense presented in first cluster in phylogenetic tree, belonging to different strains which indicated distance from other strains, proofing by their high capacity for EPS production. However, Chryseobacterium gerganium and Cloacibacterium normanence apparent in the same cluster accounts for common Cytophaga-Flavobacterium group but different genus and species. This could explain the variation in genes sequences, different metabolic pathway involved in EPS biosynthesis and difference in the amount of EPS produced.

Each EPS producing strain has a chromosome, which includes the cluster of genes necessary for biosynthesis of EPS. The EPS cluster is continent of genes sequences. The EPS cluster includes genes for synthesis of the precursors of EPS biosynthesis, and the gene for one of the enzymes in this pathway. In addition, there are genes with homologous predicted functions in regulating EPS processing and

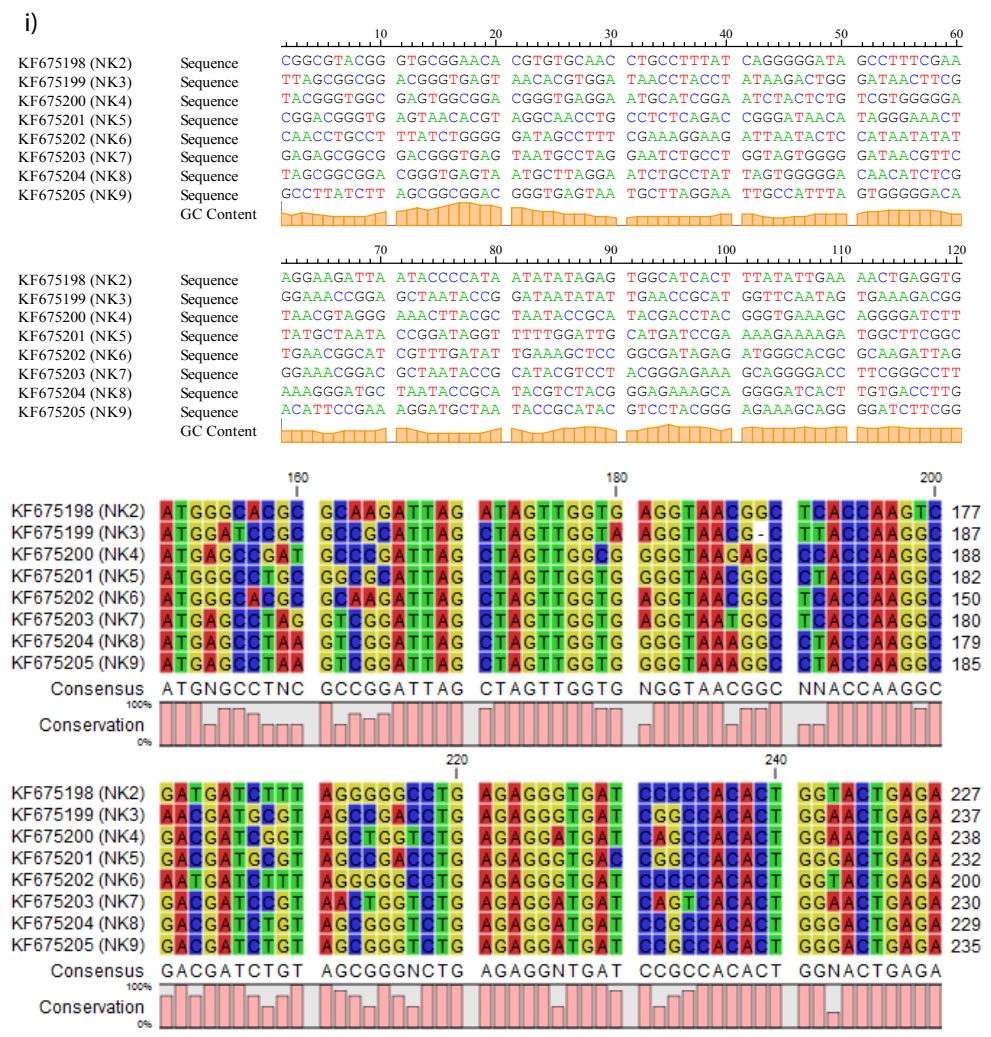

Figure 2a: Alignments of all strains isolated in present study.

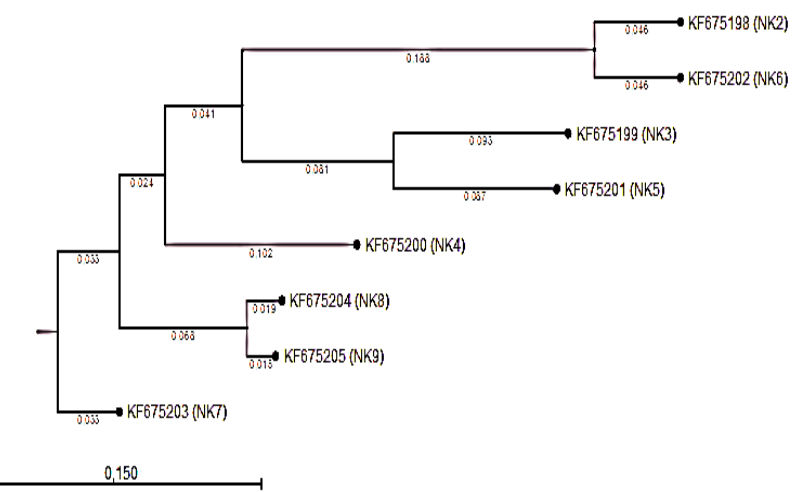

Figure 2b: Phylogenetic tree of all the isolated strains in present study. 
polymerisation, these genes are found in many EPS gene clusters.

Figures $2 \mathrm{a}$ and $2 \mathrm{~b}$ present the multiple alignments of gene sequences of different strains and phylogenetic tree. Less conservation in genes sequences among the strains was observed. Thus, a variation in glycosyltransferase genes products was responsible for the structural organisation of EPS repeating unit. This explained that the genetics organisation and transcription of the EPS genes clusters in Cloacibacteruim normanense showed significant differences from those in others strains such as Brevibacillus, or Acinetobacter. sp. Then, the variation in EPS production levels observed among the strains studied here may originate from the difference in central metabolism and the availability of sugar precursors as well as difference in the activity of enzymes of central metabolism and precursors biosynthesis.

The genetics organisation and transcription of the gene clusters from Lactobacillus rhamnaosus differ from those implicated in the synthesis of expolysaccharides in Streptococcus thermophilis. Furthermore, it was investigated that the Cytosine/Guanine (CG) content in DNA sequence may affect the EPS biosyhthesis. It was revealed a variation of CG content from 41.6 to $42.1 \mathrm{~mol} \%$ for strain Lb. rhamnaosus $\mathrm{R}$ and $L b$. rhamnaosus RW-9595M, respectively. Nevertheless, it showed the differences in amino acid sequences of ORFs (open reading frame) of the gene clusters in different strains. Among the four strains exanimined, there are few amino acid differences in the glycosyltransferrase sequences [7]. The strain Lb. rhamnosus $\mathrm{R}$ showed one amino acid difference in two glycosyltransferase gene products (Asp (Aspartic acid) to Asn (Asparagin) in WelG, and Glu (Glutamic acid) to Gly (Glycine) in WelJ) while Lb. rhamnaosus RW-6541M, showed one amino acid change (Asp to Gly in WelI) in comparison to the corresponding sequences from the others three strains ( $L b$. rhamnosus ATCC 9595, Lb. rhamansus RW-9595m and Lb. rhamnosus $\mathrm{R})$. In this context, comparing to the present study, the CG content and the change in conserved amino acid among the different strains could be one of the reasons that explained the difference in EPS concentration and composition (Figure 3a).

Most of the colanic acid (CA) genes have a high GC content (52 to $57 \%$ ) compared with that usual one (50\%) for E. coli genes, indicating that they were acquired by lateral gene transfer from another species [16]. Interestingly though, a block of three genes (wcaD, wcaE, and wcaF), have a lower GC content. This suggests that these genes have a different evolutionary history to the other genes of the cluster.

Also, the genes implicated in nucleotide sugar precursor biosynthesis may have a role in EPS biosynthesis. These genes could not be present in the EPS synthesis genes clusters and seems to be controlled by the promoter of the cps (capsular polysaccharide synthesis) clusters. Exceptionally or in some strains, it could be present and its transcription could be controlled by different promoters. Then the expression of these genes might be activated independent of the EPS biosynthesis genes to form the cell wall polysaccharides, but the co-transcription of these genes with the EPS biosynthesis genes cluster might increase the sugar precursor pool available for biosynthesis of EPS. In fact, the variation in the EPS production level among the isolated strains (in present study) may be due to the difference in the availability of sugar precursor and the enzymes responsible for EPS biosynthesis for the other strains. The research by Please incorporate reference number [7] after Péant revealed that four genes (rmlA-rmlD) exhibited significant similarity with $\mathrm{rml}$ gene products involved in the anabolism of dTDP- L-rhamnose from $a$-D-glucose 1-phosphate. EPS biosynthesis gene clusters of LAB do not generally contain these four strains. They found that its transcription is controlled by two different promoters ( $\mathrm{P} 2$ and $\mathrm{P} 3$ ). They investigated that the location of genes involved in rhamnose precursor biosynthesis within this locus, and their coordinated expression suggest the importance of this monosaccharide for biosynthesis of $L b$. rhamnosus EPS structure, where four out of seven monosaccharaides of the repeat unit are rhamnose.

Comparative analysis of EPS biosyhthesis genes clusters from strains that produce different EPS concentration is the first step to provide new insight into this industrially relevant phenotype. Many researches and present study accord that the presence of the genes encoding potential glycosyltransferases responsible for the structural organisation could be correlated well with the assembly of the EPS repeating structure. Furthermore, any variation or the difference in genes clusters involved in biosynthesis of EPS could be correlated to the variation in the amount of EPS produced among different strains.

\section{Biochemical characteristics of EPS producers}

The extracellular biopolymers synthesis by microbial cells depends on the carbon and nitrogen availability in the culture medium. Most of exopolymer-producing microorganisms utilize carbohydrates as their carbon and energy source and either ammonium salts and/or amino acids as their source of nitrogen. Therefore, the difference in EPS concentration produced by various isolated strains could be explained due to their different enzymatic machinery and their capacity to utilize different available carbon and nitrogen sources present in the sludge. Tables 2 and 3 present the carbon and nitrogen substrate utilization profiles of different strains obtained from the Biolog biochemical profiling.

All the strains isolated, particularly, Brevibacillus parabrevis (NK5) and Cloacibacterium normanense (NK6) revealed a broad spectrum of carbon and nitrogen substrate utilization profile as compared to other strains isolated in previous studies [2]. This is due to the difference in structure of strains, their capacity to assimilate carbon and nitrogen source available in the sterilized sludge, which in turn resulted in high EPS synthesis than others [14]. The synthesis of high EPS concentration by Cloacibacterium normanense (NK6) occurred in presence of some carbon source in the growth medium [14]. The availability of carbohydrates, such as: glucose, maltose, mannose and lactose in the medium contributes to high efficiency or high concentration of EPS production in the medium (Table 2). The wastewater sludge contains a variety of organic compounds including monomers, oligomers and polymers (of different molecular weights) in the form of particulate or dissolved fractions. Major chemical fractions in municipal wastewater are proteins, complex sugars, volatile fatty acids, lipids and others (humic acid, DNA-RNA, tannic acid, fibers), which could serve as raw material for bacterial strains. Utilization and the availability of glucose could have role in EPS biosynthesis. In general, EPS production increased where growth was extended by high glucose content in the medium [32].

Biolog study present that Brevibacillus parabrevis (NK5), Cloaciabacterium normanense (NK6) and Pseudomonas veronii (NK7) have high glucose assimilating capacity for EPS production. However, the concentration of EPS produced by Pseudomonas veronii (NK7) was lower than obtained by the other two strains, this could be due to the fact that it might have specific metabolic pathways to utilize complex carbon source present in the sludge to produce EPS. For example, there are different metabolic pathways between glucose and sodium acetate used as carbon source. In this case, the citric acid cycle which plays an important role in the metabolism of organic compounds and 
Citation: Nouha K, Yan S, Tyagi RD, Surampalli RY (2015) EPS Producing Microorganisms from Municipal Wastewater Activated Sludge. J Pet Environ Biotechnol 7: 255. doi:10.4172/2157-7463.1000255

Page 6 of 13

\begin{tabular}{|c|c|c|c|c|c|c|c|c|}
\hline Carbon source & $\begin{array}{c}\text { Chryseobacterium } \\
\text { gregarium }\end{array}$ & $\begin{array}{l}\text { Staphylococcus } \\
\text { epidermidis }\end{array}$ & $\begin{array}{c}\text { Stenotrophomonas } \\
\text { Acidaminiphila }\end{array}$ & $\begin{array}{c}\text { Cloacibacterium } \\
\text { normanense }\end{array}$ & $\begin{array}{c}\text { Brevibacillus } \\
\text { parabrevis }\end{array}$ & $\begin{array}{c}\text { Pseudomonas } \\
\text { veronii }\end{array}$ & $\begin{array}{c}\text { Acinetobacter } \\
\text { soli }\end{array}$ & $\begin{array}{c}\text { Acinetobacter } \\
\text { parvus }\end{array}$ \\
\hline Dextrin & + & + & + & + & + & - & - & - \\
\hline D-Maltose & + & + & + & + & + & - & - & - \\
\hline D-Trehalose & - & + & - & - & + & - & - & - \\
\hline D-Cellobiose & - & + & - & - & + & - & - & - \\
\hline Gentiobiose & + & + & - & + & + & - & - & - \\
\hline Sucrose & - & + & - & - & + & + & - & - \\
\hline D-Turanose & - & + & - & - & + & - & - & - \\
\hline Stachyose & - & - & - & - & - & - & - & - \\
\hline D-Raffinose & - & - & - & - & - & - & - & - \\
\hline a-D-Lactose & - & + & - & - & - & - & - & - \\
\hline D-Melinoise & - & + & - & - & - & - & - & - \\
\hline $\begin{array}{l}\text { b-Methyl- } \\
\text { DGlucoside }\end{array}$ & - & + & - & - & + & - & - & - \\
\hline D-Salicin & - & + & - & - & + & - & - & - \\
\hline $\begin{array}{c}\mathrm{N} \text {-acetyl- } \\
\text { Dglucosamine }\end{array}$ & - & + & + & - & + & - & - & - \\
\hline $\begin{array}{c}\mathrm{N} \text {-acetyl-b- } \\
\text { Dmannosamine }\end{array}$ & - & + & + & - & - & - & - & - \\
\hline $\begin{array}{c}\mathrm{N} \text {-acetyl- } \\
\text { Dgalactoseamine }\end{array}$ & - & + & + & - & + & - & - & - \\
\hline $\begin{array}{c}\mathrm{N} \text {-acetyl } \\
\text { neuraminic acid }\end{array}$ & - & + & - & - & - & - & - & - \\
\hline a-D-Glucose & - & + & - & + & + & + & + & - \\
\hline D-Mannose & - & - & + & + & - & - & - & - \\
\hline D-Fructose & - & + & - & - & - & - & + & - \\
\hline D-Galactose & - & + & - & - & - & - & - & - \\
\hline $\begin{array}{l}\text { 3-Methyl } \\
\text { glucose }\end{array}$ & - & + & - & - & - & - & - & - \\
\hline D-Fucose & - & + & - & - & - & - & + & - \\
\hline L-Fucose & - & + & - & - & - & + & - & - \\
\hline L-Rhamnose & + & + & - & - & - & - & - & - \\
\hline Inosine & - & + & - & - & + & - & - & - \\
\hline Glycerol & - & + & - & + & + & + & - & - \\
\hline Pectin & + & - & - & - & - & - & - & - \\
\hline $\begin{array}{c}\text { D-Galacturonic } \\
\text { Acid }\end{array}$ & + & + & + & - & - & - & - & - \\
\hline $\begin{array}{l}\text { L-Galactonic } \\
\text { acid }\end{array}$ & - & - & - & - & - & - & - & - \\
\hline lactone & - & + & - & - & + & + & + & - \\
\hline L-Gluconic acid & - & + & + & - & - & - & - & - \\
\hline Glucuronic acid & - & + & + & - & + & - & + & - \\
\hline Glucuronamide & - & + & - & - & - & - & - & - \\
\hline Mucic acid & - & + & - & - & - & - & + & - \\
\hline Quinic acid & - & + & - & - & - & - & - & - \\
\hline D-Saccharic acid & - & + & - & - & - & - & - & - \\
\hline $\begin{array}{c}\text { P-Hydroxyphenyl- } \\
\text { acetic acid }\end{array}$ & - & - & - & - & + & - & + & - \\
\hline Methyl pyuvate & - & + & - & - & - & - & + & + \\
\hline $\begin{array}{l}\text { D-Lactic acid } \\
\text { methyl ester }\end{array}$ & - & + & + & - & - & + & + & - \\
\hline L-Lactic acid & - & + & - & - & + & + & + & - \\
\hline Citric acid & - & + & + & - & + & - & + & - \\
\hline $\begin{array}{l}\text { a-Keto-glutaric } \\
\text { acid }\end{array}$ & - & + & - & - & - & - & + & - \\
\hline D-Malic acid+A72 & - & + & - & - & - & + & + & - \\
\hline L-Malic acid & - & + & - & - & - & - & + & - \\
\hline $\begin{array}{c}\text { Bromo-succinic } \\
\text { acid }\end{array}$ & - & - & - & - & - & - & + & - \\
\hline $\begin{array}{c}\text { c-Amino-butyric } \\
\text { acid }\end{array}$ & - & + & - & - & - & - & + & - \\
\hline $\begin{array}{l}\text { a-Hydroxy } \\
\text { butyric acid }\end{array}$ & - & + & - & - & + & - & + & - \\
\hline
\end{tabular}




\begin{tabular}{|c|c|c|c|c|c|c|}
\hline $\begin{array}{c}\text { b-Hydroxy-D, } \\
\text { Lbutyric acid }\end{array}$ & - & - & - & - & + & - \\
\hline $\begin{array}{c}\text { a-Keto-butyric } \\
\text { acid }\end{array}$ & - & + & - & - & + & + \\
\hline Acetoacetic acid & + & + & - & + & - \\
\hline Propionic acid & - & + & + & - & + \\
\hline Acetic acid & + & + & + & + & + \\
\hline Formic acid & - & + & - & - & + \\
\hline
\end{tabular}

Table 2: Carbon sources profiles of EPS producing Strains.

\begin{tabular}{|c|c|c|c|c|c|c|c|c|}
\hline Nitrogen sources & $\begin{array}{c}\text { Chryseobacterium } \\
\text { gregarium }\end{array}$ & $\begin{array}{c}\text { Staphylococcus } \\
\text { epidermidis }\end{array}$ & $\begin{array}{c}\text { Stenotrophomonas } \\
\text { Acidaminiphila }\end{array}$ & $\begin{array}{c}\text { Cloacibacterium } \\
\text { normanense }\end{array}$ & $\begin{array}{c}\text { Brevibacillus } \\
\text { parabrevis }\end{array}$ & $\begin{array}{c}\text { Pseudomonas } \\
\text { veronii }\end{array}$ & $\begin{array}{c}\text { Acinetobacter } \\
\text { soli }\end{array}$ & $\begin{array}{c}\text { Acinetobacter } \\
\text { parvus }\end{array}$ \\
\hline Gelatin & + & + & + & + & + & - & - & - \\
\hline Glycyl-L-proline & - & + & + & + & + & - & - & - \\
\hline L-alanine & - & + & + & - & + & - & + & - \\
\hline L-arginine & - & + & - & - & + & - & + & - \\
\hline L-aspartic acid & - & + & - & - & + & - & + & - \\
\hline L-glutamic acid & + & + & + & + & + & + & + & - \\
\hline L-Histidine & - & + & + & - & + & + & + & - \\
\hline L-Pyroglutammic acid & - & + & - & - & - & - & + & - \\
\hline L-Serine & - & + & + & + & + & - & + & - \\
\hline L-Aspartic acid & - & + & - & - & - & - & - & - \\
\hline D-Serine & - & + & - & - & + & + & - & - \\
\hline
\end{tabular}

Table 3: Nitrogen utilization profiles of all strains isolated.

the biosynthesis of microbial products could be investigated. Sodium acetate can enter the citric cycle directly, but glucose and starch have to be degraded to pyruvate and then oxidized to form acetyl- CoA before it enters the citric acid cycle [17]. The degradation and uptake of readily biodegradable organic substrates probably resulted in a high level of exoenzymes in the EPS matrix [4].

Low nitrogen content in the growth environment also influences extensively the microbial synthesis of extracellular biopolymers [19]. The high content and availability of nitrogen sources in the medium induce extracellular protein production by microbial cells. Cloacibacterium normanense (NK6) and Brevibacillus parabrevis (NK5) utilized almost all nitrogen sources such as gelatin, glycyl-Lproline, L-glutamic acid and L-serine compared to other strains, which explain the high protein content of EPS produced by these strain as compared to the EPS of other strains (Table 3).

The strains isolated in the present work are totally different than those presented by More [2]. They found that the bacillus species had high spectrum of carbon utilization except bacillus sp. 1 and Bacillus sp. 9 which utilized few carbon sources compared to other strains. In present study, it was revealed that some of the strains such as Cloacibacterium normanense, Acinetobacter parvus and Chryseobacterium gregarium utilized very few carbon sources; they still produced high EPS concentration compared to bacillus sp. This could be due to the fact that they had specific metabolic pathways which helped to utilize complex nutrients and carbon sources available in the sludge. Sometimes Biolog systems are insensitive to certain bacterial structure due to their metabolic redundancy. Species composition could change with or without a shift in the profile of the positive responses. In addition, every species has specific genetic elements and their genes clusters encode for EPS production. Their high expression could increase the availability of precursors and the enzymes which utilize specific and different substrates involved in the anabolism of sugar nucleotide precursors responsible for EPS biosynthesis. That's why sometimes the EPS produced by bacterial strains displays a great variety of structure, and many are heteropolysaccharides composed of different sugar moieties (glucose, galactose, rhamnose, mannose, $\mathrm{N}$-acetyl glucosamine).

\section{Factors affecting microbial community}

In present work, the isolated strains were totally different from those isolated by Subramanian [14] even from same activated sludge. This could be explained by considering environmental factors that affected the bacterial community. Some of these factors are called modulators. Examples of modulators are temperature, $\mathrm{pH}$ and salinity.

The intrinsic property of the microbial community is genotypically determined through the adaptation of the populations present to the selective pressure. The strains (NK2-NK9) isolated in this study in July 2013 were totally different from the strains (BS1-BS25) isolated by Subramanian et al. [14] in January, 2010. In response to changes in season (summer/winter), the microbial community composition and biomass can change. For example, microbes will change the composition of their membrane fatty acids after a change in temperature [20]. A change in the environment will therefore induce a selection pressure, which will gradually shift the growth optima of the community. If the environment changes to a situation far from the initial optimum conditions for the bacterial community, a shift will occur in the composition of the community. In this case, the variation of temperature could be a reason for the diversity and change of microbial community in present study comparing to bacteria isolated by Subramanian [14]. Firstly, it is suggested that the optimal temperature growth of strains isolated by Subramanian was less than $10^{\circ} \mathrm{C}$ according to the data required by WWTP, CUQ. The temperature of WWTP in winter was almost between 4 and $10^{\circ} \mathrm{C}$. However in summer, it was higher than $10^{\circ} \mathrm{C}$ and can reach to $15^{\circ} \mathrm{C}$. Secondly, it could be another reason that there were organisms better suited to the new environmental conditions which would grow and compete other organisms, or existing organisms will undergo evolutionary adaptation. Species of the microbial community can rapidly adapt even to momentary changes in the local environment [20]. The sensitivity 
to environmental change and disturbance differs among the bacterial communities and it depends on the species.

On the other hand, comparison with to the previous studies [2], some of bacillus strains were isolated in this study, but they were different species, it could be suggested that Brevibacillus parabrevis adapted to the change in temperature and it could be a mutation in its gene clusters which introduce another phenotype or genotype of bacillus sp. However, the total diversity and change in microbial community in present study could be explained by part of microbial community died and replaced by other microbial community species and genus [20]. Davis and Shaw [21] suggested that adaptive responses of vegetation to climate change occurred at many levels, including phenotypic plasticity, genetic adaptation, succession and migration processes. If there is a drastic change in the environment, part of the community will die preparing for more tolerant species to take over. If a strong selection pressure is exerted, this can favour certain genotypes or mutants and thus introduce new genotypes in the community. A less dramatic change in the environment can lead to phenotypic changes in the population.

Many researchers reported seasonal variation correlating environmental factors with bacterial community and function. The seasonality of microbial communities in different ecosystems has been well documented, with little attention being paid to the activated sludge (AS) system [22], in which the seasonal dynamics of microbial communities greatly affects the performance and stability of pollutants removal. As reported by Ju [23], microbial communities in AS were predominated by bacteria. The abundance of bacteria in summer was $87.8 \pm 2.8 \%$, which was lower than that in winter $(91.0 \pm 1.6 \%)$. On one hand, abundance of Actinobacteria (phylum) was usually higher in winter $26.0 \pm 3.1 \%$ than in summer $17.9 \pm 6.9 \%$, with abundance ratio of summer to winter of 0.7. Actinobacteria sp. decreased with increasing salinity. Changes in salinity affect bacterial cell by changing their osmotic environment, causing stress on the membranes and proteins structures. Taking consideration into that, the salts could be a reason causing stress and high EPS production for some bacteria as well as a disadvantage to some others for their growth. Here, the high salinity of water in winter season could be explained by the high quantity of salt added in the winter season used to melt ice. In present study, most of strains isolated have shown growth only in presence of $1 \%$ of $\mathrm{NaCl}$ as Acinetobacter sp, Pseudomonas veronii and Chryseobacterium gregarium, some of them resist $4 \%$ of $\mathrm{NaCl}$ to grow as Brevibacillus parabrevis and some others no growth in $\mathrm{NaCl}$ medium as Cloacibacterium normanense. This could be a reason that this type of bacteria were not found in previous studies Subramanian [14]. However, most of the Bacillus spp. isolated in winter by Subramanian and characterized by biolog test by More, [2] have shown growth in presence of $1 \%, 4 \%$ and $8 \% \mathrm{w} / \mathrm{v} \mathrm{NaCl}$, except Bacillus sp. 1 which could not grow at $8 \% \mathrm{w} / \mathrm{v} \mathrm{NaCl}$. EPS producing Bacillus spp. were resistant to high salt stress conditions which were also reported by Upadhyay [24]. Further, in engineered systems, e.g. in wastewater treatment plants, it has recently been suggested that the diversity of specific bacterial groups in activated sludge influences the functioning of the reactor. The presence of many microorganisms is able to conduct a specific process and increases the probability that a change of environmental conditions does not worsen the effectiveness of wastewater treatment, since one of the species will adapt and maintain the specific metabolic pathway [23]. Taking this into consideration, the operational parameters of the wastewater treatment plant should be selected to favour the development of a highly diversified bacterial community. Cydzik-Kwiatkowska [26] reported the impact of operational parameters on bacterial community.
Firstly, it was found that richness of microorganisms was correlated with organic load rate $\left(B_{C}\right)$ of the system. During the year of sampling $\mathrm{B}_{\mathrm{C}}$ varied from 0.09 to $0.21 \mathrm{~g}$ COD.g TSS ${ }^{-1} \cdot \mathrm{d}^{-1}$ and bacteria richness increased with increasing $\mathrm{B}_{\mathrm{C}}$. At a very high $\mathrm{B}_{\mathrm{C}}$, the diversity tends to decrease because a large quantity of organic carbon in wastewater stimulates dynamically growing bacteria with a very short generation time and these compete out other species and dominate the bacterial population. Similar results were obtained by Xia [27] who investigated the microbial community structure in response to different ratios of carbon to nitrogen (C/N of 3:1, 5:1, and 10:1) in wastewater sludge. The carbon content as well as $\mathrm{C} / \mathrm{N}$ ratio of activated sludge collected in 2010 by Subramanian was different from those collected in 2013 in present research, Secondly Valentin [28]reported that biochemical oxygen demand (BOD), influent total suspended solid (TSS), solid retention time (SRT), food/microorganisms $(\mathrm{F} / \mathrm{M})$, seem to have the strongest influence on the bacterial communities composition in the bio-reactors. The very low values of $\mathrm{F} / \mathrm{M}$ in the wastewater treatment plant suggest that the microbial community was starving contributing to high mortality rate among the microbial populations. Similarly, some of these factors could be the stress causing and responsible for the change of the diversity of microbial community between the present and previous study $[2,3]$.

\section{EPS production and characteristics}

All the bacterial strains were individually cultivated in sterilized sludge under similar growth conditions to ascertain their capacity of EPS production. The sludge had total solids (TS) concentration of 11.3 $\pm 0.6 \mathrm{~g} / \mathrm{L}$, suspended solid (SS) concentration of $9.7 \pm 1.2 \mathrm{~g} / \mathrm{L}$ and $\mathrm{pH}$ of $6.2 \pm 0.2$. The range of the maximum concentration of EPS harvested from different strains after $48 \mathrm{~h}$ of fermentation was $1.6 \pm 0.2-11.8 \pm 1.2$ $\mathrm{g} / \mathrm{L}$ (Figure 3a). The control sample of the sterilized sludge (without inoculation) contained EPS concentration of $1.9 \pm 0.2 \mathrm{~g} / \mathrm{L}$, whereas the control sludge without sterilization incubated for $48 \mathrm{~h}$ revealed $0.9 \mathrm{~g} / \mathrm{L}$ \pm 0.1 EPS concentration.

The concentration of EPS produced by Cloacibacterium normanense (NK6) $(11.8 \pm 1.2 \mathrm{~g} / \mathrm{L})$ and by Brevibacillus parabrevus $(3.5 \pm 0.5 \mathrm{~g} / \mathrm{L})$ was higher than the other bacterial strains reported in this work (Table 4) as well as that of Serratia sp. (3.4 g/L) reported in previous work $[2,3]$. Further, the production of EPS in sterilized sludge was higher the maximum concentration of $3.2 \mathrm{~g} / \mathrm{L}$ obtained in synthetic media [14].

The EPS production was correlated with increase in viscosity of the fermented broth. High viscosity of the fermented broth was

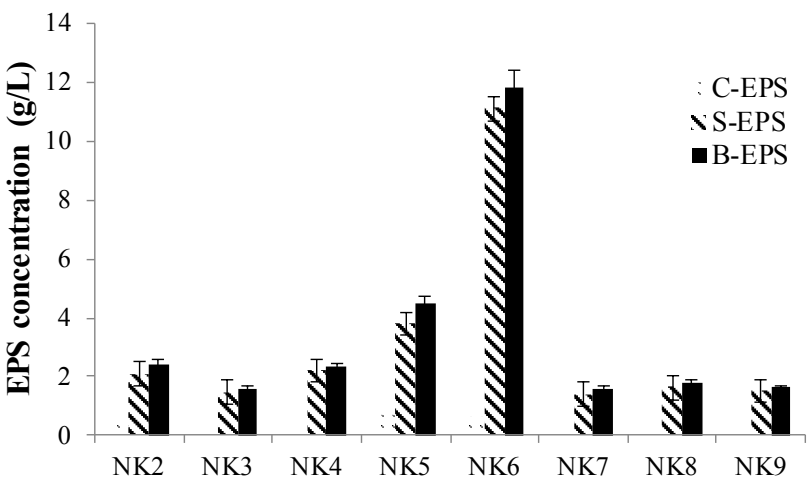

Bacterial strains isolated

Figure 3a: EPS concentrations produced by 8 bacterial strains at the end of 3 days of fermentation at initial $\mathrm{pH} 7.0$. 
Citation: Nouha K, Yan S, Tyagi RD, Surampalli RY (2015) EPS Producing Microorganisms from Municipal Wastewater Activated Sludge. J Pet Environ Biotechnol 7: 255. doi:10.4172/2157-7463.1000255

Page 9 of 13

\begin{tabular}{|c|c|c|c|c|c|c|}
\hline \multicolumn{7}{|c|}{ Flocculation Activity (FA) \% } \\
\hline \multicolumn{3}{|c|}{ TB-EPS } & Broth EPS & \multicolumn{3}{|l|}{ LB-EPS } \\
\hline Strains & EPS (mg/g kaolin) & FA (\%) & EPS (mg/g kaolin) & FA (\%) & EPS (mg/g kaolin) & FA (\%) \\
\hline \multirow{4}{*}{ Chryseobacterium gregarium } & $0.4 \pm 0.2$ & $30.4 \pm 3.4$ & $0.4 \pm 0.2$ & $24.1 \pm 0.6$ & $0.04 \pm 0.1$ & $44.0 \pm 3.4$ \\
\hline & $0.8 \pm 0.3$ & $59.5 \pm 2.5$ & $0.6 \pm 0.3$ & $19.0 \pm 2.6$ & $0.06 \pm 0.2$ & $46.0 \pm 1.9$ \\
\hline & $1.4 \pm 0.2$ & $57.3 \pm 1.9$ & $0.8 \pm 0.4$ & $38.5 \pm 3.3$ & $0.08 \pm 0.3$ & $53.6 \pm 4.6$ \\
\hline & $1.8 \pm 0.3$ & $74.0 \pm 1.3$ & $1.0 \pm 0.4$ & $72.8 \pm 2.3$ & $0.16 \pm 0.1$ & $57.8 \pm 3.8$ \\
\hline \multirow{4}{*}{ Staphylococcus epidermidis } & $0.2 \pm 0.1$ & $8.2 \pm 2.8$ & $0.4 \pm 0.02$ & $7.5 \pm 6.3$ & $0.02 \pm 0.01$ & $13.1 \pm 4.2$ \\
\hline & $0.6 \pm 0.3$ & $13.7 \pm 4.6$ & $0.6 \pm 0.09$ & $11.2 \pm 3.9$ & $0.04 \pm 0.02$ & $15.7 \pm 5.1$ \\
\hline & $1.0 \pm 0.6$ & $17.2 \pm 1.9$ & $0.8 \pm 0.11$ & $15.3 \pm 3.7$ & $0.08 \pm 0.04$ & $44.9 \pm 3.9$ \\
\hline & $1.2 \pm 0.1$ & $31.4 \pm 2.2$ & $1.0 \pm 0.14$ & $29.4 \pm 2.8$ & $0.12 \pm 0.065$ & $51.9 \pm 4.1$ \\
\hline \multirow{4}{*}{ Stenotrophomonas acidaminiphila } & $0.4 \pm 0.2$ & $32.6 \pm 1.4$ & $1.2 \pm 0.2$ & $61.1 \pm 2.9$ & $0.2 \pm 0.05$ & $24.8 \pm 0.5$ \\
\hline & $0.8 \pm 0.9$ & $68.8 \pm 2.4$ & $2.4 \pm 0.3$ & $61.9 \pm 1.7$ & $0.3 \pm 0.1$ & $24.9 \pm 2.3$ \\
\hline & $1.4 \pm 1.2$ & $48.5 \pm 2.3$ & $3.6 \pm 0.9$ & $53 \pm 2.4$ & $0.4 \pm 0.09$ & $39.4 \pm 2.8$ \\
\hline & $1.8 \pm 1.3$ & $77.2 \pm 1.6$ & $4.8 \pm 0.6$ & $57 \pm 2.5$ & $0.5 \pm 0.02$ & $53.3 \pm 4.1$ \\
\hline \multirow[b]{2}{*}{ Cloacibacterium normanense } & $0.10 \pm 0.05$ & $69.9 \pm 3.0$ & $1.15 \pm 0.1$ & $81.0 \pm 1.9$ & $1.1 \pm 0.2$ & $85.1 \pm 1.5$ \\
\hline & $\begin{array}{l}0.20 \pm 0.10 \\
0.42 \pm 0.10 \\
0.55 \pm 0.10\end{array}$ & $\begin{array}{l}79.4 \pm 3.1 \\
77.5 \pm 2.0 \\
68.5 \pm 2.3\end{array}$ & $\begin{array}{l}2.36 \pm 0.2 \\
4.72 \pm 0.1 \\
7.08 \pm 0.4\end{array}$ & $\begin{array}{l}89.4 \pm 2.3 \\
86.2 \pm 2.5 \\
82.3 \pm 3.1\end{array}$ & $\begin{array}{l}2.3 \pm 0.1 \\
4.6 \pm 0.1 \\
6.9 \pm 0.2\end{array}$ & $\begin{array}{l}90.4 \pm 0.9 \\
88.2 \pm 1.4 \\
82.3 \pm 2.3\end{array}$ \\
\hline \multirow{4}{*}{ Brevibacillus parabrevis } & $0.4 \pm 0.1$ & $83.2 \pm 2.3$ & $0.6 \pm 0.1$ & $46.9 \pm 3.4$ & $0.02 \pm 0.01$ & $32.7 \pm 1.2$ \\
\hline & $0.6 \pm 0.2$ & $77.6 \pm 1.6$ & $1.2 \pm 0.1$ & $79.4 \pm 3.2$ & $0.04 \pm 0.01$ & $47.2 \pm 1.3$ \\
\hline & $1.0 \pm 0.2$ & $71.9 \pm 1.9$ & $1.8 \pm 1.3$ & $71.5 \pm 2.3$ & $0.06 \pm 0.01$ & $51.7 \pm 2.1$ \\
\hline & $1.4 \pm 0.2$ & $69.5 \pm 2.1$ & $2.4 \pm 0.9$ & $61.7 \pm 1.9$ & $0.08 \pm 0.01$ & $69.8 \pm 1.8$ \\
\hline \multirow{4}{*}{ Pseudomonas Veronii } & $0.3 \pm 0.2$ & $35.5 \pm 1.3$ & $0.28 \pm 0.05$ & $44.9 \pm 3.7$ & $0.03 \pm 0.01$ & $60.7 \pm 1.7$ \\
\hline & $0.7 \pm 0.2$ & $55.1 \pm 1.8$ & $0.56 \pm 0.04$ & $46.2 \pm 3.5$ & $0.06 \pm 0.02$ & $64.4 \pm 2.5$ \\
\hline & $1.0 \pm 0.6$ & $47.2 \pm 2.1$ & $0.84 \pm 0.18$ & $27.6 \pm 1.85$ & $0.09 \pm 0.03$ & $61.6 \pm 2.7$ \\
\hline & $1.3 \pm 0.1$ & $48.8 \pm 2.4$ & $1.12 \pm 0.11$ & $33.5 \pm 2.3$ & $0.12 \pm 0.04$ & $58.3 \pm 1.8$ \\
\hline \multirow{4}{*}{ Acinetobacter soli } & $0.03 \pm 0.02$ & $49.8 \pm 1.9$ & $0.2 \pm 0.12$ & $50.1 \pm 0.8$ & $0.03 \pm 0.01$ & $45.1 \pm 1.5$ \\
\hline & $0.06 \pm 0.03$ & $52.5 \pm 1.3$ & $0.4 \pm 0.03$ & $55.3 \pm 1.4$ & $0.07 \pm 0.02$ & $46.9 \pm 1.3$ \\
\hline & $0.10 \pm 0.05$ & $65.5 \pm 0.5$ & $0.6 \pm 0.02$ & $50.7 \pm 1.5$ & $0.10 \pm 0.03$ & $40.8 \pm 0.9$ \\
\hline & $0.12 \pm 0.04$ & $43.1 \pm 2.4$ & $0.8 \pm 0.12$ & $53.2 \pm 2.2$ & $0.12 \pm 0.02$ & $45.3 \pm 2.1$ \\
\hline \multirow{4}{*}{ Acinetobacter parvus } & $0.03 \pm 0.04$ & $28.5 \pm 1.1$ & $0.2 \pm 0.02$ & $17.7 \pm 1.7$ & $0.04 \pm 0.01$ & $20.4 \pm 2.9$ \\
\hline & $0.06 \pm 0.01$ & $34.5 \pm 2.3$ & $0.4 \pm 0.03$ & $27.4 \pm 2.6$ & $0.08 \pm 0.08$ & $33.9 \pm 1.6$ \\
\hline & $0.10 \pm 0.01$ & $62.5 \pm 3.4$ & $0.6 \pm 0.09$ & $10.5 \pm 2.3$ & $0.12 \pm 0.06$ & $34.7 \pm 3.5$ \\
\hline & $0.12 \pm 0.01$ & $40.3 \pm 1.5$ & $0.8 \pm 0.06$ & $17.7 \pm 1.8$ & $0.20 \pm 0.04$ & $48.5 \pm 1.9$ \\
\hline \multirow{4}{*}{ Control } & $0.2 \pm 0.1$ & $32.1 \pm 2.3$ & $0.2 \pm 0.1$ & $2.9 \pm 0.8$ & $0.02 \pm 0.01$ & $32.2 \pm 1.9$ \\
\hline & $0.4 \pm 0.2$ & $35.7 \pm 4.2$ & $0.4 \pm 0.2$ & $16.6 \pm 1.7$ & $0.04 \pm 0.03$ & $37.2 \pm 1.6$ \\
\hline & $0.6 \pm 0.2$ & $32.6 \pm 1.7$ & $0.6 \pm 0.2$ & $19.4 \pm 4.5$ & $0.06 \pm 0.01$ & $42.8 \pm 2.5$ \\
\hline & $0.8 \pm 0.3$ & $30.1 \pm 3.5$ & $0.8 \pm 0.3$ & $32.5 \pm 2.6$ & $0.08 \pm 0.04$ & $40.2 \pm 2.5$ \\
\hline
\end{tabular}

Table 4: Kaolin clay flocculation activity obtained for different types of EPS for isolated strains.

solely due to the increase in EPS concentration. The fermented broth of Cloacibacterium normanense (NK6) and Brevibacillus parabrevis (NK5) exhibited the highest viscosity of $85.7 \pm 1.9$ and $18.8 \pm 1.5$ $\mathrm{mPa}$, respectively. The viscosity of the broth of NK5 and NK6 was also higher than the EPS producing strains reported by More et al. [2], who reported the maximum viscosity of $5.8 \pm 0.3 \mathrm{mPa}$. The reason for higher viscosity in the present case was due to higher concentration of EPS produced.

On the other hand, Figure $3 \mathrm{~b}$ revealed that the EPS production by all the isolated strains while growing in the sterilized activated sludge closely related to the bacterial cell concentration. Cloacibacterium normanensestrain (NK6) attained the highest cell count of $7.5 \times 10^{8}$ $\mathrm{CFU} / \mathrm{mL}$ at $48 \mathrm{~h}$ followed by Brevibacillus parabrevis (NK5) (Figure $3 \mathrm{~b}$ ) with cell count of $1.29 \times 10^{8} \mathrm{CFU} / \mathrm{mL}$ in $24 \mathrm{~h}$. The $\mathrm{pH}$ increased in case of NK6 from 7 to 9 , whereas for the other strains the $\mathrm{pH}$ decreased from 7 to 4 (Figure 4). This difference in $\mathrm{pH}$ could be explained by the

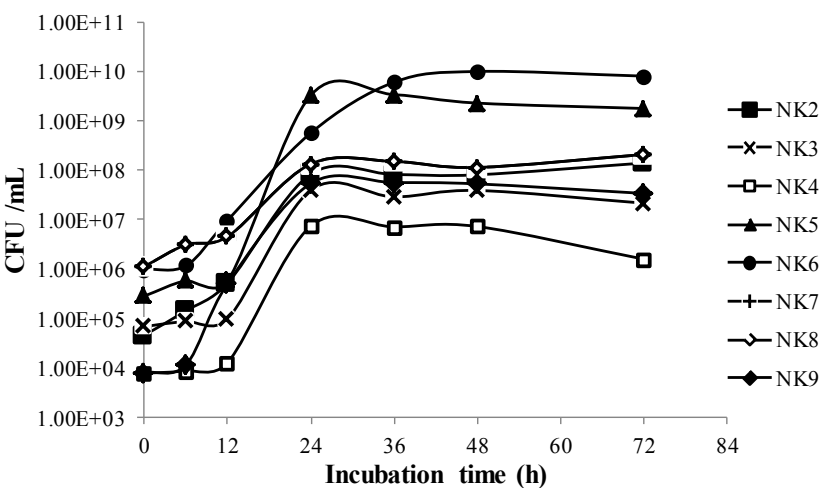

Figure 3b: Growth profiles of different strains isolated. 
chemical nature of EPS, which varies in terms of carbohydrates, protein, nucleic acid, lipids, and humic substances. The presence of uronic acids (such as glucuronic, galacturonic and mannuronic acid) or common substitutes like acetate ester, pyruvate ketals, formates, succinates and inorganic (phosphate ans sulfate) decides the nature (neutral, anionic or cationic) of EPS macromolecules which affect the $\mathrm{pH}$.

\section{Flocculation activity}

Flocculation activity (FA) of B-EPS, LB-EPS and TB-EPS for all isolated bacteria was studied and results are presented in Table 4. The general trend of flocculation activity for all strains is an increase of FA with an increase in EPS concentration (ranged 0.2 $7.0 \mathrm{mg} / \mathrm{g}$ Kaolin for B-EPS and LB-EPS and up to $0.03 \mathrm{mg} / \mathrm{g}$ kaolin for TB-EPS). Cloacibacterium normanense, Brevibacillus parabrevis, Stenotrophomonas acidaminiphila and Chryseobacterium gregarium showed higher flocculation activities of $89.8 \pm 1.2,79.4 \pm 3.2 \%, 77.0$ $\pm 1.6 \%$ and $74.0 \pm 1.3 \%$ respectively in concentration range between 1.2-2.4 mg B-EPS/g kaolin. For other strains, the flocculation activity of B-EPS ranged between $61-69 \%$. Lower flocculation activity for some bacterial strains may be due to lower EPS concentration added which ranged between $0.6 \pm 0.1-1.2 \pm 0.2 \mathrm{mg}$ B-EPS/g Kaolin. In missing present study, the highest flocculation activity was $90.2 \pm 2.3 \%$ in case of Cloacibacterium normanense (NK6) with the addition of $2.4 \pm 0.3$ $\mathrm{mg}$ LB-EPS/g kaolin. The highest flocculation activity $83.2 \%$ in case of Brevibacillus parabrevis (NK5) using $0.4 \mathrm{mg}$ TB-EPS /g kaolin was also recorded. EPS concentration required to attain maximum flocculation activity was $2.30 \mathrm{mg} \mathrm{LB}-\mathrm{EPS} / \mathrm{g}$ kaolin and $2.36 \mathrm{mg} \mathrm{B-EPS/g} \mathrm{kaolin} \mathrm{in}$ case of Cloacibacterium normanense (NK6); following with $0.36 \mathrm{mg}$ LBEPS/g Kaolin and $1.20 \mathrm{mg}$ for Brevibacillus parabrevis. The flocculation activity of $90.2 \pm 2.3 \%$ and $83.2 \pm 2.3 \%$ reported in the present study

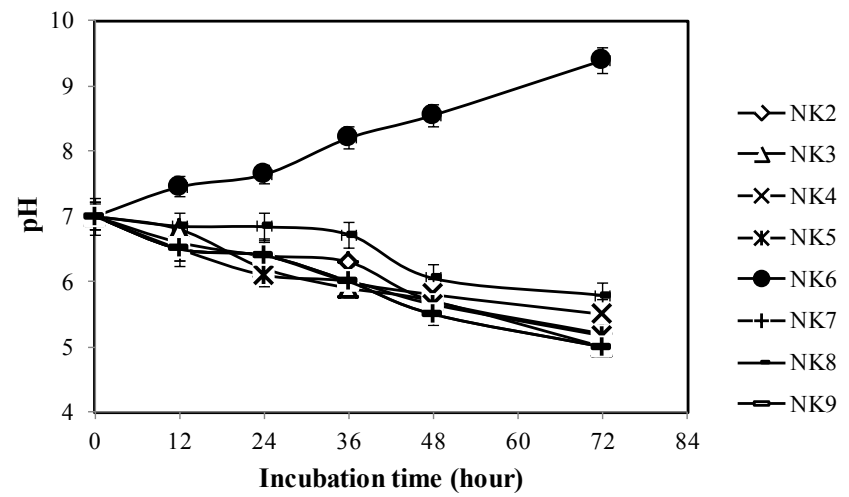

Figure 4: Variation of $\mathrm{pH}$ during the fermentation. was higher than $81.7 \%$ (B-EPS) produced by Bacillus sp.7 [2,3]

Furthermore, the concentration of B-EPS added was between 1.12$2.70 \mathrm{mg}$ EPS/g Kaolin to attain high flocculation activity (>75\%) [2], whereas EPS produced in the synthetic media by the same bacterial strain required 250-2500 mg EPS/g Kaolin to attain similar flocculation activity [14]. The lowest concentration of S-EPS to achieve maximum FA in the present work was $2.3 \mathrm{mg} / \mathrm{g}$ kaolin. The most efficient EPS produced by different strains are compared in Table 5. A lower concentration of EPS is required to achieve higher FA with the new strains isolated in this study which is advantageous from an economic standpoint.

Effect of EPS composition on flocculation activity: Three bacterial strains (NK2, NK3 and NK4) displayed an increased flocculation activity with the increased EPS concentration, whereas five strains (NK5, N6, N7, NK8 and NK9) showed a decreasing trend with increasing B-EPS concentration (Table 4). B-EPS contains both EPS (LB-EPS \& TB-EPS) and residual material of fermentation medium as well as other unknown metabolites. Therefore, flocculation activity might be affected by these factors and by the variation of protein and carbohydrate content of the EPS. Protein and carbohydrate content of EPS varies with the type of bacterial strain.

The carbohydrate content of TB-EPS was high in case of NK2, NK7, NK8 and NK9 comparing to NK5 and NK6 (Figure 5b). However, the carbohydrate content of S-EPS was almost similar in case of all strains. For the protein content, it was high in LB-EPS and TB-EPS for all the strain, except the LB-EPS of NK6 which contain less protein content (Figure 5a).

According to these results, high flocculation activity (83.2 \pm $2.3 \%$ ) of TB-EPS was achieved in case of NK5. However, the highest flocculation of LB-EPS was $90.2 \pm 2.5 \%$ in case of NK6. This may be due to the chemical composition of protein and carbohydrate content in LB-EPS, which contain more groups with positive charge that helps good flocculation. Furthermore, the high FA could also be possible due to the fact that LB-EPS was long polymeric chain biopolymers which may also possess more active sites to bind with the colloidal particles and other microorganisms comparing to TB-EPS [14]. In the present study, it can be suggested that the low carbohydrate content and high protein content increase the flocculation activity. On the other side, low flocculation activity had been presented by other bacterial strains (NK2, NK3, NK4, NK8, NK9) with high protein content. This could be due to different structures and types of protein produced by these strains $[2,3]$.

Effect of zeta potential on FA: The zeta potential value at $\mathrm{pH} 7$ of LB-EPS, TB-EPS and B-EPS for all the strains isolated ranged between

\begin{tabular}{|c|c|c|c|c|c|c|c|}
\hline This Work & EPS (g/L) & $\begin{array}{l}\text { FA (\%) } \\
\text { (B-EPS) }\end{array}$ & $\begin{array}{l}\text { FA (\%) } \\
\text { LB-EPS }\end{array}$ & $\begin{array}{l}\text { Strains of More } \\
\text { et al., (2012) }\end{array}$ & EPS (g/L) & $\begin{array}{l}\text { FA (\%) } \\
\text { (B-EPS) }\end{array}$ & $\begin{array}{l}\text { FA (\%) } \\
\text { (LB-EPS) }\end{array}$ \\
\hline Chryseobacterium gregarium & 2.4 & 74.0 & 72.8 & Bacillus sp.2 & 1.27 & 69.0 & 65.0 \\
\hline Staphylococcus epidermidis & 1.6 & 31.4 & 29.4 & Bacillus sp.5 & 1.24 & 63.0 & 45.4 \\
\hline $\begin{array}{l}\text { Stenotrophomonas } \\
\text { acidaminiphila }\end{array}$ & 2.3 & 77.2 & 61.9 & Bacillus sp. 6 & 1.45 & 76.5 & 56.0 \\
\hline Cloacibacterium normanense & 11.8 & 89.9 & 90.2 & Bacillus sp.7 & 1.56 & 81.7 & 63.5 \\
\hline Brevibacillus parabrevis & 3.5 & 79.4 & 83.2 & Bacillus sp.8 & 1.65 & 55.0 & 68.1 \\
\hline Pseudomonas veronii & 1.6 & 55.1 & 44.9 & Bacillus sp.9 & 1.23 & 56.0 & 53.0 \\
\hline Acinetobacter soli & 1.8 & 65.5 & 55.3 & Serratia sp.1 & 1.51 & 57.0 & 56.0 \\
\hline Acinetobacter parvus & 1.6 & 62.5 & 27.4 & Serratia sp.1 & 1.51 & 57.1 & 56.3 \\
\hline Lowest ESP for Max FA (\%) & \multicolumn{3}{|c|}{$0.09-0.1 \mathrm{mg} / \mathrm{SS}$} & & \multicolumn{3}{|c|}{$1.12-2.7 \mathrm{mg} / \mathrm{Ss}$} \\
\hline
\end{tabular}

Table 5: Comparison of FA (\%) results between present work and previous studies. 

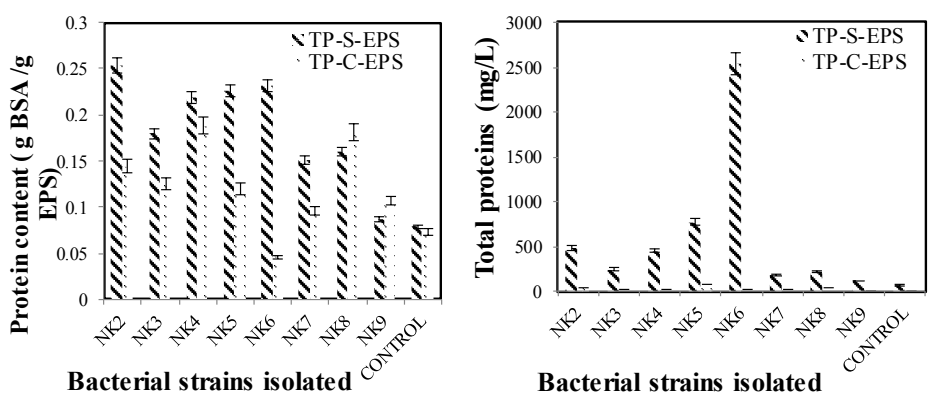

Figure 5a: Total proteins (TP) content and protein concentration of EPS produced by different bacterial strains in sterilized sludge.
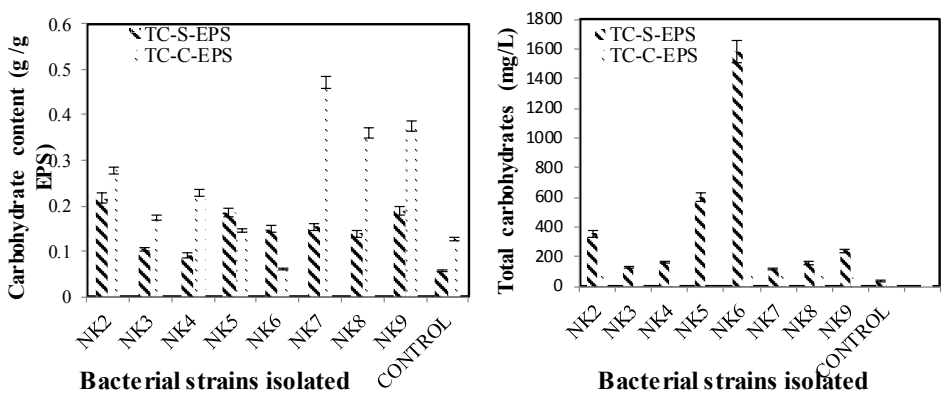

Figure 5b: Total carbohydrate (TC) content and carbohydrate concentration produced by different bacterial strains in sterilized sludge.

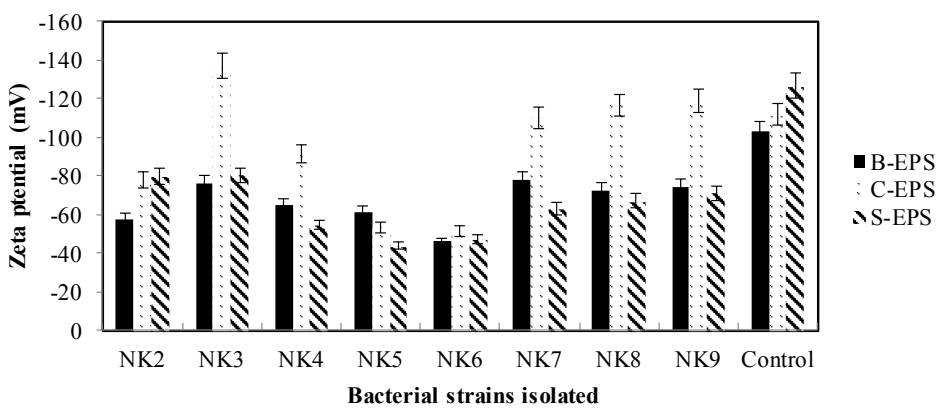

Figure 6: Zeta potential values of S- EPS, C- EPS and B-EPS produced by different bacterial strains in sterilized sludge.

$-47.8 \pm 0.4$ and $-129.2 \pm 9.1$ (Figure 6). The control sample charge was between $-126.5 \pm 5.1$ and $-103.1 \pm 4.2 \mathrm{mV}$, which revealed a higher negative charge than the EPS samples (EPS from bacterial strains).

The zeta potential of LB-EPS produced by bacterial strain NK6 was the highest $(-47.8 \pm 0.4 \mathrm{mV})$, which revealed its better kaolin flocculation activity. These values of zeta potential were approximately in the same range (from -54.2 to $-35.6 \mathrm{mV}$ ) as obtained by Subramanian [14] from selected six bacterial strains. Thus, higher value of zeta potential correlates to higher flocculation activity. Cells with higher negative surface charge would have lower floc strength and poorer flocculating properties. The reason is that the increased negative surface charge would lead to increased repulsive electrostatic interactions between approaching surfaces according to the DLVO theory, and therefore cause a weaker bonding between the cells. However, a better kaolin FA as well as one of the lowest CST value (48.4 s) for bacterial strain (BS8 or Serratia sp.) with the lowest zeta potential $(-54.2 \mathrm{mV})$ was reported by Subramanian. Thus, the EPS charge is not related to floc formation, which is concurrent with the reported literature $[2,3,14]$.
The variation of charge, on different EPS (slime, capsular and broth EPS) produced by different strains was due to different microorganisms may produce EPS of different chemical composition (different functional groups) and properties. The differences in the properties of polysaccharides and proteins of EPS can lead to different charges. For example, higher quantity of basic amino acids in EPS gives higher positive charge while the existence of higher acidic amino acids in the protein and hydroxyl group in polysaccharides (part of EPS) gives higher negative charge. In this case, the $\mathrm{pH}$ also plays an important role, when the $\mathrm{pH}$ increases; the carboxyl group in protein is ionized furnishing a negative charge. Moreover, the presence of capsular EPS (TB-EPS) on the cell surface can reduce the negative surface charge of microorganisms to a certain extent. Surface charge of the fresh sludge before inoculation $(-79.5 \pm 4.7 \mathrm{mV})$ used in this study revealed a higher negative charge than the EPS produced by all the strains (Figure 6) and it was higher than reported by Subramanian $(-35.0 \mathrm{mV})$. The possible reason for higher sludge-surface charge may be due to the fact that the sludge, in addition to EPS (proteins, carbohydrates, lipids, DNA and RNA), is also composed of various other components including 
microorganisms, humic substances and solids, which may contribute to higher anionic charge.

The EPS produced by 8 bacterial strains, in bacterial broth at $\mathrm{pH}$ 7 are also anionic in nature (Figure 6). The zeta potential value of LBEPS produced had relatively less negative charges compared to B-EPS and TB-EPS. In this context, this can be argued that the S-EPS contains higher positively charged groups than other type of EPS (Broth and capsular). The EPS can be composed of many charged groups such as carboxyl, phosphoric, sulfhydryl, phenolic and hydroxyl groups. Many apolar groups (e.g., aromatics, aliphatics in proteins, and hydrophobic regions in carbohydrates) were characterised the EPS. Moreover, the hydrophobicity is very important property of the EPS.

The hydrophobicity is very important property of the EPS. Hydrophobicity results from the behaviour of EPS particles or molecules, which are incapable of interacting electrostatically or establishing hydrogen bonds with water and induce hydrophobic properties into the EPS matrix. This causes the EPS matrix or parts to aggregate together and separate from the water. Then, the presence of hydrophilic and hydrophobic groups in EPS molecules indicate the relative ratio of two groups is related to the composition of EPS. According to the study of Yuan [29], the hydrophobicity values were all below $50 \%$ for the LB-EPS, while a hydrophobic part of approximately $71 \%$ was observed in the corresponding protein or polysaccharide component of the TB-EPS. Therefore, the high flocculation activity observed in this study could be because of the high hydrophobicity values of protein present in LB-EPS. Moreover, the decrease in flocculation activity has been shown, after attaining maximum value (Table 4). This could be explained by an over dosage of the polymer that might have caused the re-suspension or instability of kaolin particles, which would lead to the high turbidity. EPS concentration is directly related to sludge flocculation [30]. In case of sludge also an optimum EPS concentration is required for maximum flocculation. Excess EPS concentration is detrimental to sludge dewatering.

\section{Conclusions}

Eight bacterial strains capable of producing EPS using sterilized sludge as raw material were isolated and identified. The EPS production variation among the strains was revealed. The EPS, produced by isolated bacterial strains were characterized in terms of proteins and carbohydrates. Cloacibacterium normanense produced the highest concentration $(11.8 \pm 1.2 \mathrm{~g} / \mathrm{L})$ of EPS. S-EPS exhibited kaolin flocculation activity of $90 \%$ using very low concentrations $(2.36 \mathrm{mg}$ of EPS/g Kaolin) following by Brevibacillus parabrevis. The variation of EPS concentration produced could be due to many reasons. The initial information to address the metabolic cause of the low production levels of EPS suggest that increased EPS precursor availability, in combination with elevated enzyme activity levels involved in the specific EPS biosynthesis pathway, might enhance EPS production. Then the recent advances in analysis of physiology and genetics of strain producing EPS allow control of their metabolic activity not only by changing the fermentation conditions but also by applying genetic technique that result in the overexpression of existing or novel genes [31].

\section{Acknowledgement}

Sincere thanks to the Natural Sciences and Engineering Research Council of Canada (Grant A 4984, Canada Research Chair) for financial support. The views and opinions expressed in this paper are those of the authors.

\section{References}

1. Abu-Orf MM, Griffin P, Dentel SK (2001) Chemical and physical pre-treatment of ATAD biosolids for dewatering. Water Science and Technology 44: 309-314.
2. More TT, Yan S, Hoang NV, Tyagi RD, Surampalli RY (2012a) Biochemical diversity of the bacterial strains and their biopolymer producing capabilities in wastewater sludge. Bioresource Technology 121: 304-311.

3. More TT, Yan S, Hoang NV, Tyagi RD, Surampalli RY (2012b) Bacterial polymer production using pre-treated sludge as raw material and its flocculation and dewatering potential. Bioresource Technology 121: 425-431.

4. Nielsen PH, Frolund B, Keiding K (1996) Changes in the composition of extracellular polymeric substances in activated sludge during anaerobic storage. Appl Microbiol Biotechnol 44: 823-830.

5. Wingender J, Neu TR, Flemming HC (1999) Microbial Extracellular Polymeric Substances: Characterization, Structure and Function. Springer-Verlag, Berlin Heidelberg, New York

6. Sobeck DC, Higgins MJ (2002) Examination of three theories for mechanisms of cationinduced bioflocculation. Water Res 36: 527-538.

7. PéantB, etal. (2005)Comparativeanalysis of the exopolysaccharide biosynthesis gene clusters from four strains of Lactobacillus rhamnosus. Microbiology 151: 1839-1851.

8. Cain D, Hanks H, Weis M, Bottoms C, Lawson J (2009) Microbiology Laboratory Manual. Collin County Community College District, McKinney, TX.

9. Lee J, Kim SM, Jung JY, Oh BS, Kim IS, Hong SK (2009) Analysis of tota bacteria, enteric members of -proteobacteria and microbial communities in seawater as indirect indicators of quantifying biofouling, Environ Eng Res 14 (1).

10. APHA (2005) Standard methods for the examination of water and wastewater $21^{\text {st }}$ ed. American Public Health Association, Washington, DC

11. Bradford MM (1976) A rapid and sensitive method for the quantitation of microgram quantities of protein utilizing the principle of protein-dye binding. Anal. Biochem 72: 248-254.

12. Dubois M, Gilles KA, Hamilton JK, Rebers PA, Smith F (1956) Colorimetric method for determination of sugars and related substances. Analytical Chemistry 28: 350-356.

13. Zhang Z, Xia S, Zhang J (2010) Enhanced dewatering of waste sludge with microbial flocculant TJ-F1 as a novel conditioner. Water Research 44: 3087 3092.

14. Subramanian BS, Yan S, Tyagi RD, Surampalli RY (2010) Extracellula polymeric substances (EPS) producing bacterial strains of municipal wastewater sludge: isolation, molecular identification, EPS characterization and performance for sludge settling and dewatering. Water Research 44: 2253 2266.

15. Hay ID, Rehman ZU, Moradali MF, Wang Y, Rehm BH (2013) Microbial alginate production, modification and its applications. Microb Biotechnol 6: 637-650.

16. Stevenson G, Andrianopoulos K, Hobbs M, Reeves PR (1996) Organization of the Escherichia coli K-12 gene cluster responsible for production of the extracellular polysaccharide colanic acid. J Bacteriol 178: 4885-4893.

17. Sutherland IW (2001) Microbial polysaccharide from Gram negative bacteria Int Dairy J 11: 663-674.

18. Madigan MT, Marrtinko JM, Parker J (1997) Brock Biology and Microbiology, $8^{\text {th }}$ ed. Prentice Hall, New Jersey, USA.

19. Sleytr UB (1997) Basic and applied S-layer research: an overview. FEMS Microbiol. Rev 20: 5-12.

20. Finlay BJ, Maberly SC, Cooper JI (1997) Microbial diversity and ecosystem function. Oiko 80: 209-213.

21. Davis MB, Shaw RG (2001) Range shifts and adaptive responses to Quaternary climate change. Science 292: 673-679.

22. Kim TS, Jeong JY, Wells GF, Park HD (2013) General and rare bacterial taxa demonstrating different temporal dynamic patterns in an activated sludge bioreactor. Appl Microbiol Biotechnol 97: 1755-1765.

23. Ju F, Guo F, Lin Ye, Xia Y, Tong, Zhang (2013) Metagenomic analysis on seasonal microbial variations of activated sludge from a full-scale wastewater treatment plant over 4 years. Environmental Microbiology Reports 6: 80-89.

24. Upadhyay SK, Singh JS, Singh DP (2011) Exopolysaccharide-producing plant growth-promoting rhizobacteria under salinity condition. Pedosphere 21: 214-222.

25. LaPara TM, Nakatsu CH, Pantea LM, Alleman JE (2002) Stability of the 
Citation: Nouha K, Yan S, Tyagi RD, Surampalli RY (2015) EPS Producing Microorganisms from Municipal Wastewater Activated Sludge. J Pet Environ Biotechnol 7: 255. doi:10.4172/2157-7463.1000255

Page 13 of 13

bacterial communities supported by a seven-stage biological process treating pharmaceutical wastewater as revealed by PCR-DGGE. Water Res 36: 638-646.

26. Cydzik-Kwiatkowska A, Wojnowska-Baryła I (2012) Impact of Operational Parameters on Bacterial Community in a Full-Scale Municipal Wastewater Treatment Plant. Pol J Microbiol 61: 41-49.

27. Xia S, Duan L, Song Y, Li J, Piceno YM, Andersen GL, et al. (2010) Bacterial community structure in geographically distributed biological wastewater treatment reactors. Environ Sci Technol 44: 7391-7396.

28. Valentin-Vargas A, Toro-Labrador G, Massol-Deya AA (2012) Bacterial Community Dynamics in Full-Scale Activated Sludge Bioreactors: Operational and Ecological Factors Driving Community Assembly and Performance. PLoS ONE 7(8)

29. Yuan ZG, Oehmen A, Peng YZ, Ma Y, Keller J (2008) Sludge population optimization in biological nutrient removal wastewater treatment systems through on-line process control: A review. Rev Environ Sci Biotechnol 7: 243-254.

30. Houghton J, Quarmby J, Stephenson T (2001) Municipal wastewater sludge dewaterability and the presence of microbial extracellular polymer. Water Sci Technol 44: 373-379.

31. Gagnon B, Ziadi N (2004) Value of paper mill sludge in agriculture: crop yield, soil properties, and environmental impacts. Rec Res Develop Crop Sci 1: 1-10. 